Beata Udzik ${ }^{1}$

Uniwersytet im. A. Mickiewicza w Poznaniu

DOI: https://doi.org/10.26881/jsr.2021.16.02

\title{
LICEALIŚCI PISZĄ O KONSEKWENCJACH PODEJMOWANYCH DECYZJI. ANALIZA WYBRANYCH PRZYKLADÓW JEZZYKOWEJ KONCEPTUALIZACJI WYBORU W PRACACH Z MATURY PRÓBNEJ
}

\begin{abstract}
Celem edukacji polonistycznej w perspektywie aksjologii jest umiejętne wprowadzanie w tradycję poprzez indywidualne oddziaływanie na kształtowanie się sytemu wartości wychowanka, ukazywanie różnorodnych koncepcji człowieka i świata oraz konsekwencji dokonywanych wyborów. Język polski jako przedmiot nauczania umożliwia nawiązanie i odwołanie się do tradycji we wszystkich płaszczyznach edukacji polonistycznej: kształcenia kulturalno-literackiego, kształcenia językowego, oddziaływania przekazów medialnych.
\end{abstract}

(Kurczab 2012, s. 8)

Artykuł powstaje w momencie, gdy uczniowie liceów i techników przygotowują się do wyjątkowego w swoim życiu wydarzenia, jakim jest egzamin maturalny. W polskiej tradycji edukacyjnej jest on uznawany za najważniejszy sprawdzian wiedzy i umiejętności. Etymologia nazwy wywodzi słowo od łacińskiego maturus 'dojrzały, dorosły'. Historia egzaminu maturalnego w Polsce ${ }^{2}$ - co uświadamia m.in. przeprowadzona przez Jerzego Kaniewskiego analiza matury pisemnej z języka polskiego - pokazuje, że sprawdzaniu zawsze poddawane były: materiał rzeczowy będący przedmiotem nauczania w szkole (zazwyczaj dotyczący dzieł literackich), sposób jego ujęcia, dobór przykładów, logika wypowiedzi, poprawność argumentacji, kompozycja tekstu, sprawność językowo-stylistyczna i poprawność językowa (Kaniewski 2017, s. 31).

\footnotetext{
${ }^{1}$ udzik@amu.edu.pl, https://orcid.org/0000-0002-7794-9084

${ }^{2} \mathrm{~W}$ różnych okresach funkcjonowania egzaminu z języka polskiego zmieniały się tematy, co miało związek z polską historią XIX i XX w., zwłaszcza z zaborami (zniesieniem języka polskiego jako obowiązkowego w pewnych okresach) czy czasami PRL (silnym kontekstem ideologicznym i propagandowym charakterem tematów maturalnych).
} 
W czasie pandemii wyjątkowość sytuacji egzaminacyjnej ulega swoistemu zwielokrotnieniu: niemal 11 miesięcy nauka odbywała się za pośrednictwem różnorodnych form zdalnej komunikacji. Uczniowie i nauczyciele stanęli przed niespotykanym dotychczas wyzwaniem przygotowania do egzaminu w warunkach nauczania zdalnego. To nowa sytuacja pod względem organizacyjnym, metodycznym, a ponadto bardzo często także emocjonalnym. Ministerstwo opublikowało wymagania egzaminacyjne, w których pominięto niektóre elementy i zmodyfikowano arkusz egzaminacyjny (powiększono pulę tematów wypracowania do wyboru), a Centralna Komisja Egzaminacyjna zaproponowała arkusz egzaminu próbnego.

Celem niniejszego artykułu jest przedstawienie wyników analizy 81 prac z matury próbnej przeprowadzonej w marcu $2021 \mathrm{r}$. w liceum w 25-tysięcznym mieście powiatowym $^{3} \mathrm{z}$ wykorzystaniem arkuszy zaproponowanych przez komisję. Dobór próby badawczej nie rości sobie prawa do reprezentatywności, jest raczej diagnozą sytuacji in statu nascendi. Chcę zwrócić uwagę na wartościowy badawczo materiał empiryczny pochodzący z prac uczniowskich, który - poddany refleksji - daje obraz stanu umiejętności tekstotwórczych uczniów liceum tu i teraz. Proponowana analiza ma na celu przyjrzenie się wstępom do rozprawek licealistów, w których najpełniej ujawniają się: sposób rozumienia zadania, językowa konceptualizacja kluczowych słów tematu oraz sprawność wyrażania własnego stanowiska.

Zenon Uryga w klasycznej już dziś dla dydaktyki polonistycznej książce Godziny polskiego wskazał cztery przenikające się wymiary edukacji polonistycznej. Za autorem książki wymiar instrumentalny rozumiem jako wyposażanie uczniów w narzędzia i umiejętności niezbędne do uczenia się wszystkich innych treści kształcenia ogólnego (Uryga 1996, s. 14). Szczególnie istotne w kontekście podejmowanej analizy wypracowań licealistów okazuje się uczenie pisania. Ma ono służyć opanowaniu umiejętności językowego wyrażania myśli w spójnym wywodzie.

Tworzenie wypowiedzi argumentacyjnych wymaga ponadto sprawności, które Jolanta Nocoń dzieli na trzy grupy: krytyczne myślenie, porządkowanie przebiegu rozważań na poziomie globalnym i lokalnym, posługiwanie się specyficznymi środkami stylowymi i językowymi. Myślenie krytyczne i refleksyjne polegać ma według badaczki na zajmowaniu postawy badawczej zarówno wobec różnych rodzajów informacji, jak i wobec różnych sposobów ich hierarchizowania i relatywizowania. Wymaga to całościowego myślenia o mającym powstać tekście oraz jego sekwencjach. Wśród czynności cząstkowych składających się na ten etap pracy badaczka wymienia: analizę tematu, wyodrębnienie z niego problemu, jego rozważenie, sformułowanie własnego zdania i dobranie argumentacji dowodzącej jego słuszności / broniącej go (Nocoń 2016, s. 321-337).

${ }^{3}$ Uczniowie kończący to liceum uzyskują rokrocznie wyniki na poziomie podstawowym do $10 \%$ wyższe od wyników krajowych. 
Każdy dorosły człowiek posługujący się językiem ojczystym powinien umieć wyrazić w nim własne zdanie, zająć stanowisko wobec sądów, opinii czy poglądów innych ludzi. Podstawą wykształcenia ogólnego jest bowiem kompetencja komunikacyjna, na którą według Stanisława Grabiasa (1994) składają się sprawności: systemowa, społeczna oraz pragmatyczna. Absolwent przystępujący do egzaminu maturalnego na poziomie podstawowym nie tylko zna system i reguły pozwalające na budowanie poprawnych wypowiedzi, nie tylko dostosowuje swą wypowiedź do sytuacji egzaminacyjnej, ale także jest świadomy celu, jaki wpisany został w konwencję gatunkową realizowanej wypowiedzi, ponieważ - jak pisze Agnieszka Mikołajczuk (2013, s. 40) - „tekst pisany przez uczniów na egzaminie maturalnym powinien mieścić się w konwencji gatunkowej wybranych modeli wypowiedzi pisemnej”".

Choć rozprawka to jedynie szkolna forma wypowiedzi, stworzona „dla potrzeb, celów i zadań edukacji szkolnej" (Informator ..., s. 186), to przecież rozwijana podczas procesu kształcenia polonistycznego służy kształtowaniu wielu ważnych umiejętności. Uczeń potrafiący napisać rozprawkę to uczeń, który formułuje własne stanowisko w postaci tezy lub hipotezy oraz uzasadnia je w spójnej, funkcjonalnie skomponowanej i stosownej w warstwie stylistycznej wypowiedzi pisemnej, przestrzegając zasad poprawności językowej, ortograficznej oraz interpunkcyjnej.

Wymiar formacyjny lekcji polskiego, w tym zwłaszcza kształtowanie w ich ramach umiejętności pisania, realizuje się poprzez odsłanianie przed uczniem wiedzy o człowieku i świecie, w wymiarze egzystencjalnym, wspartym refleksją psychologiczną, socjologiczną czy filozoficzną. Zofia Agnieszka Kłakówna pisze następująco:

szkoła z definicji niejako [...] ma oferować swoim uczniom jakieś zasady oglądania świata i tworzenia w sobie niezbędnego człowiekowi ładu. Aby zaś służyć nauce świadomego uczestnictwa w dzisiejszej kulturze, której znamieniem stała się efemeryczność, szkoła musi tworzyć warunki zauważania owej efemeryczności, a to znaczy dystansowania się od niej. Warunkiem dystansu jest «ustawianie się» na zewnątrz. W interesującym nas zakresie nie jest to możliwe bez elementarnych nawyków uważnej postawy wobec języka (Kłakówna 2016, s. 373).

Temat pierwszy zaproponowany w arkuszu matury próbnej z języka polskiego na poziomie podstawowym w $2021 \mathrm{r}$. miał formę pytania otwartego - pytania o uzupełnienie. Dotyczył problemu ważnego z perspektywy formacyjnych zadań edukacji, czyli wyborów, których dokonuje człowiek. Zakładał też, że piszący powinien rozważyć konsekwencje podejmowanych decyzji, a więc ich wpływ na życie człowieka. 
Postawiony problem pozostaje zagadnieniem istotnym dla człowieka wkraczającego w dorosłość, który ma rozważyć następstwa podejmowanych w życiu działań. Na tym etapie są to oczywiście następstwa działań bohaterów literackich. Literatura może w takim przypadku spełniać funkcję swoistego symulatora sytuacji życiowych i najczęściej tak jest przez uczniów traktowana. Na poziomie podstawowym tekst literacki (tekst kultury) rzadko staje się przedmiotem analiz, w których uczniowie uruchamialiby przewidziane w podstawie programowej i kształcone podczas lekcji umiejętności (narzędzia) z zakresu analizy i interpretacji tekstu. Świat przedstawiony dzieła literackiego traktowany jest głównie jako odzwierciedlenie sytuacji realnych, przyjmowany jako wysoce prawdopodobny, więc mogący stanowić przedmiot oceny, np. w kategoriach etycznych. Wykorzystanie tekstu literackiego następuje więc głównie w trybie dowodowym czy ilustracyjnym wobec przyjętego stanowiska (rozwiązania problemu ujętego w zadaniu maturalnym - temacie), znacznie rzadziej w trybie rozważającym czy analitycznym ${ }^{4}$.

W procesie konkretyzacji dzieła literackiego zawsze dochodzi do uzupełnień i przekształceń dokonanych przez czytelnika (Ingarden 1967, s. 45-46). Bożena Chrząstowska i Agata Wójtowicz-Stefańska podkreślają, że odbiór dzieła sztuki jest procesem zindywidualizowanym, zależnym zarówno od sytuacji egzystencjalnej odbiorcy (w przypadku odbioru ucznia - procesem zależnym przede wszystkim od etapu rozwoju poznawczego i emocjonalnego), jak i od materii samego dzieła (Chrząstowska, Wójtowicz-Stefańska 2011, s. 180).

W zadaniu maturalnym zarówno fragment tekstu literackiego, jak i cały tekst wykorzystane zostają instrumentalnie, ponieważ wpisuje się je w nadrzędny problem wskazany $\mathrm{w}$ temacie, a jego odbiór ukierunkowany zostaje przez kryteria oceniania pracy egzaminacyjnej. Przewidują one, że maturzysta przyjmie własne stanowisko wobec problemu i je uzasadni. Z kolei uczeń piszący pracę dokonuje kolejnej instrumentalizacji fragmentu tekstu, ponieważ nie interpretuje jego sensów w ujęciu całościowym; jedynie wybiera z niego te treści, które uznaje za zgodne z własną linią argumentacyjną.

W realizowanym przez uczniów temacie wypracowania wyróżnić można elementy stałe, tj. dyspozycje identyfikujące gatunek: „rozważ, „uzasadnij”, „odwołując się”, oraz elementy zmienne, czyli określenie problemu do rozważenia i materiału literackiego będącego podstawą rozważania: „Jak wybory człowieka wpływają na jego życie? Rozważ problem, odwołując się do fragmentu Pana Tadeusza, całego utworu Adama Mickiewicza oraz do wybranego tekstu kultury. Twoja praca powinna liczyć co najmniej 250 wyrazów" (Test diagnostyczny 2021, s. 2). Słowa kluczowe pojawiające się w treści zadania muszą stać

${ }^{4}$ Odwołuję się tutaj do opisanych już wcześniej sposobów przywołań fragmentów i całych tekstów literackich w wypracowaniach maturzystów (Udzik 2019). 
się podstawą do zbudowania punktu wyjścia późniejszych rozważań, nierzadko bywają też powtarzane w pointach akapitów lub w zakończeniu.

Słownikowe definicje słowa wybór eksponują jego czynnościowy charakter: 'wybranie czegoś spośród dwóch lub więcej możliwości' (WSJP PAN); 'wybranie, wybieranie spomiędzy pewnej liczby osób, rzeczy’ (WSJP PWN). Piszący jednak bardzo często posługiwali się leksemem decyzja, traktując go jako synonim słowa wybór: 'rozstrzygnięcie dokonywane po zastanowieniu' (WSJP PAN); 'postanowienie, rozstrzygnięcie, będące wynikiem przemyśleń' (WSJP PWN).

Najnowszy aktualizowany słownik współczesnej polszczyzny kwalifikuje tematycznie obydwa leksemy - wybór i decyzja - do kategorii 'człowiek jako istota psychiczna' i podkategorii 'działalność intelektualna człowieka'. Wybór to 'nazwa działania intelektualnego człowieka', a decyzja - 'wytwór działań intelektualnych człowieka' (WSJP PAN). Piszący traktują oba słowa synonimicznie i używają ich wymiennie. Zauważalnym problemem poprawnościowym staje się łączliwość obu wyrazów, których związki ulegają kontaminacji. Stąd dużą frekwencję wykazują połączenia: dokonywać/dokonać decyzji, podjaćc/ podejmować wybór.

Analiza prac licealistów pozwala odkryć, jak uczniowie rozumieją i językowo konceptualizują sytuację wyboru i jej wpływ na życie człowieka. Aby przeprowadzić tę analizę, wyznaczono dwa wcześniej zdefiniowane słowa klucze tematu, wokół których ogniskują swoje stanowisko licealiści. Są nimi słowa wybór (stosowane wymiennie ze słowem decyzja) oraz wpływać (zastępowane często nominalnym derywatem wptyw). Wstępy do rozprawek zawierają nawiązanie do tematu i wyrażenie stanowiska autora pracy wobec głównego problemu, stąd to właśnie w tym miejscu wypracowania pojawiają się najczęściej słowa klucze tematu.

Sposób pisania o wyborach życiowych ujawnia zarówno kulturowy, jak $\mathrm{i}$ indywidulany punkt widzenia autorów prac. $Z$ jednej strony sytuacja egzaminacyjna, waga pracy maturalnej oraz znajomość tekstów kultury poznawanych w całym procesie edukacji każą interpretować zagadnienie w kategoriach powagi samej sytuacji wyboru oraz jego konsekwencji. Z drugiej strony autor wypracowania, chcąc wyrazić własny punkt widzenia, odwołuje się do codziennych sytuacji, które nie przystają najczęściej do literackich czy kulturowych przykładów bohaterów i dramatyzmu ich położenia w momencie dokonywania wyboru. „Metafora punktu widzenia obrazuje lingwistyczne aspekty poznania jako zjawisko indywidualne, podobne indywidualności widzenia. Używana jest ona jednak głównie w sensie «grupowym», w sensie punktów widzenia utrwalonych w języku" (Zinken 2004, s. 77).

Autorzy rozprawek, pisząc o wyborach lub podejmowanych decyzjach, posługują się głównie sekundarnie wartościującymi leksemami łatwy 'taki, który nie stwarza kłopotów' (WSJP PAN) i trudny 'taki, w którym przeważają kłopoty 
i trudności' (WSJP PAN). Łatwy wybór to także wybór prosty, błahy, oczywisty, mniej ważny. Przywołane leksemy umniejszają wagę wyboru, ponieważ jego ilustracją bywają sytuacje życiowe: jest to łatwa sprawa, jak np. wybór, co chcemy zjeść na śniadanie; co zjeść na śniadanie lub w co się ubrać; czy zatożyć czarne spodnie i niebieska koszulę czy może jednak zielona; dobór ubrania, decyzja o tym, co zje się na śniadanie; ludzie [...] wybieraja władze samorzadowe i krajowe, musza zdecydować, co ubrać lub co zrobić w danej sytuacji.

Przykłady pokazują, że uczniowie odwołują się do podstawowych sytuacji egzystencjalnych, zatem stosują język potoczny. Ten z kolei odzwierciedla potoczną świadomość, o której pisał Jacek Warchala: „przemiany kulturowe otwierają drzwi dla wszechogarniającej potoczności, zarówno w sposobie myślenia, jak i mówienia oraz konstruowania wypowiedzi pisemnych" (Warchala 2013, s. 184);

Fakty, zjawiska, przedmioty codzienności są przez nas porządkowane według zasad logiki potocznej. Dzielimy rzeczy zgodnie z zasadą tworzenia kolekcji elementów współistniejących i mających konkretne przeznaczenie, a nie wyabstrahowanych klas typologicznych. Chleb, kromka, nóż, masło, kroić, smarować, śniadanie, herbata - to nie logicznie uporządkowana klasa elementów, lecz kolekcja tu i teraz występujących przedmiotów oraz czynności należących do sfery jedzenia czy kojarzących się nam z kuchnią i posiłkami. To swoista pamięć sytuacji, która tworzy podstawy indywidualnego oraz subiektywnego widzenia znaczeń i sensów (Warchala 2003, s. 33).

W wielu przypadkach licealiści posługują się uogólnieniem, w którym odwołanie do codzienności służy podkreśleniu kontrastu między łatwym a trudnym wyborem: jedne sa błahe i dotycza problemów dnia codziennego, od innych zależy nasze życie. Takie dychotomiczne ujęcie występuje w wielu pracach.

$\mathrm{W}$ analizowanym korpusie prac akapity wprowadzające zawierają charakterystyczne dla wypracowań uczniowskich słownictwo służące podkreśleniu powszechnego charakteru doświadczeń oraz wprowadzeniu szerokiego tła czasowego. Kategorie temporalne uwypuklają wagę samej sytuacji wyboru, ponieważ podkreślają wielokrotność, a dalej ciągłość jej występowania, np. codziennie musimy zmagać się z różnymi decyzjami; każdy z nas codziennie musi podejmować wiele decyzji; czlowiek w czasie swojej egzystencji niejednokrotnie zmuszony jest do podejmowania wielu decyzji; czlowiek $w$ swoim życiu bardzo często musi dokonywać wyborów; życie to ciagłe podejmowanie wyborów; człowiek w ciagu całego swojego życia musi dokonywać wielu wyborów. W analizowanym materiale można też znaleźć metafory kładące nacisk na powszechność zjawiska: pasmo wyborów, fala wyborów.

Wyborom przypisywane są cechy związane z kategoriami świadomości i emocji (nieprzemyślane, niezrozumiałe, pod wptywem emocji, emocjonalne, 
spontaniczne), korzyści (niekorzystne, korzystne, najkorzystniejsze), skutku (ryzykowne, nieodwracalne, przełomowe, niewybaczalne), trafności (właściwe, niewłaściwe), dobra i zła (złe, najgorsze). Podejmowane decyzje wpływają na innych ludzi, stąd autorzy prac nazywają je krzywdzacymi czy niewybaczalnymi. Wybory bywają też konieczne, co wyklucza sprawczość podmiotu podejmującego decyzję. Stąd już blisko do dramatycznych i tragicznych wyborów, o których licealiści także piszą.

Ponieważ zadanie zakładało konieczność odwołania się do fragmentu Pana Tadeusza, w którym Jacek Soplica podczas spowiedzi przedstawia okoliczności śmierci Stolnika i zdarzenia będące ich następstwem, uczniowie w swoich pracach podkreślali głównie negatywne skutki podejmowanych decyzji. Słowa określające sytuację dokonywania wyboru lub jego konsekwencje to trud, ból, cierpienie, pułapka.

Kolejnym słowem kluczowym dla podejmowanego tematu jest leksem wpływać, który za słownikami definiować można następująco: 'swoim działaniem lub samą obecnością powodować, że określona czynność proces lub czyjeś zachowanie przebiega inaczej, niż gdyby danego obiektu lub działania nie było' (WSJP PAN); 'odbić się (odbijać się) na czymś, przyczynić się (przyczyniać się) w jakimś stopniu do czegoś' (WSJP PWN). Czasownik wpływać wymaga obligatoryjnie wypełnienia drugiego argumentu w konstrukcji wplywać na kogo? co?. W zadaniu należało rozważyć wpływ na życie człowieka poprzez odpowiedź na pytanie o sposób, co sygnalizuje się w zadaniu pytaniem otwartym rozpoczynającym się od wykładnika pytania o sposób: jak.

Wypowiedzi na temat wpływu dokonywanych przez człowieka wyborów na jego życie sprowadzone zostają przez licealistów najczęściej do określenia intensywności oddziaływania. Jeśli rozwiązanie konceptualizowane jest w postaci odpowiedzi na pytanie ,jak wpływają?”, to wyrażają je przysłówki: znaczaco, istotnie, w znacznym stopniu, diametralnie, bardzo, w sposób nieodwołalny. Część autorów prac podaje odpowiedź niejednoznaczną: różnie, wielorako. Również w odpowiedziach zawierających znominalizowaną formę leksemu w postaci rzeczownika wpływ występują przymiotniki określające stopień wpływu: ogromny, olbrzymi, niewielki, znaczacy, decydujący, różny, większy lub mniejszy. W kategoriach dobra i korzyści wpływ oceniany jest jako pozytywny lub negatywny.

W większości wypracowań maturzystów przyjęto stanowisko, że wybory człowieka wpływają destrukcyjnie na jego życie. Pociągają za sobą konsekwencje, które najczęściej są poważne, negatywne, a nawet nieodwracalne. Podjęte decyzje determinuja, kompletnie zmieniaja, zaburzaja rytm życia, wpływaja strasznie, prowadza do tragedii, niszcza, powoduja wyrzuty sumienia, obracaja życie do góry nogami.

Wybór zatem konceptualizowany jest jako PUNKT, MOMENT ZWROTNY w życiu jednostki. To, co po nim następuje, ma wpływ na dalsze życie człowie- 
ka, przynosi jakąś ZMIANĘ, która najczęściej wartościowana jest NEGATYWNIE. Ważnymi kategoriami chrakteryzującymi dokonywanie wyborów w życiu są KONIECZNOŚĆ i NIEODWRACALNOŚĆ. Przed podejmowaniem decyzji nie można uciec, są one bowiem stałym elementem ludzkiego życia. Znaczną trudność autorom wypowiedzi sprawia językowe wyrażenie owej dialektyki stałości i zmiany: wybory są nieodłącznym, a więc powtarzającym się elementem ludzkiego życia, a jednocześnie przynoszą zmianę.

Taki sposób wartościowania w kategoriach nieodwracalności jest konsekwencją załączonego do zadania fragmentu „Pana Tadeusza”. Uczeń, realizując zadanie maturalne, powinien sformułować stanowisko adekwatne do tematu i dołączonego do niego fragmentu. Przywołane poniżej przykłady realizacji wstępu ilustrują najczęściej spotykane w badanym materiale sposoby konceptualizowania problemu postawionego $\mathrm{w}$ zadaniu:

Każdy z nas w swoim życiu musi dokonywać wyborów. Moga to być błahe, tatwe decyzje lub trudne, majace wptyw na nasze dalsze życie. Każdy podjęty wybór niesie ze soba konsekwencję. Wybory człowieka moga w różny sposób wptywać na jego życie;

$W$ ciagu życia czlowiek stawiany jest przed rozmaitymi wyborami. Podejmowane przez nas decyzje ksztattuja nasz los, określaja nasza pozycję $i$ wptywaja na bieg wydarzeń, czego odzwierciedlenie można znaleźć w literaturze;

Ludzkie życie przepetnione jest trudnościami i pułapkami. Człowiek musi podejmować decyzje, które dopiero po uptywie czasu ujawniaja czy byty dobre czy też złe. Nie ma ucieczki od życiowych wyborów. Człowiek może jedynie zasięgnąć porady, poszukać informacji, ale decyzję musi podjać sam. Warto jednak zastanawiać się i przeanalizować problem zanim cokolwiek zrobi. Pytanie tylko, co to da? Decyzje podjęte szybko, bez zastanowienia przeważnie nie okazuja sie dobre, ale to wcale nie jest reguła. Dlatego wybory człowieka wptywaja dobrze, a czasem źle na jego życie ${ }^{5}$.

Przywołane przykłady dowodzą zrozumienia problemu podanego w temacie przy jednoczesnym podkreślaniu niejednoznaczności odpowiedzi na zadane pytanie. Maturzyści nie odpowiadają precyzyjnie, jak wybory wpływają na życie człowieka. Nie formułują jasno swojego stanowiska, nie potrafią sformułować tezy, która nie byłaby ogólnikową formułą, ale zapowiadała dalej przywoływane argumenty - przykłady.

Zaproponowany uczniom temat związany był niewątpliwie $\mathrm{z}$ formacyjnym wymiarem przedmiotu i nakazywał odwołanie do lektury obowiązkowej. Jego realizacje w uczniowskich wypracowaniach okazywały się na ogół adekwatne do problemu. Pozwoliły też na śledzenie uczniowskiego zmagania się ze słowem i wartościowaniem, w którym najtrudniejsze ciągle pozostają umiejętności zło-

${ }^{5}$ Zapis przykładów zgodny z oryginałami. 
żone: kategoryzowanie, uogólnianie, jasne określenie stanowiska, które antycypuje przywoływane dalej argumenty świadczące o umiejętności dystansowania się zarówno wobec świata przedstawionego w utworze literackim, jak i wobec własnego języka opisu tegoż świata.

\section{Bibliografia}

Chrząstowska B., Wójtowicz-Stefańska A. (2011), Umiejętności odbioru dzieta sztuki, w: Innowacje i metody. W kręgu teorii i praktyki. Podręcznik akademicki dydaktyki ksztatcenia polonistycznego, red. M. Kwiatkowska-Ratajczak, Poznań.

Egzamin maturalny. Język polski - poziom podstawowy. Test diagnostyczny, Wypracowanie (2021), https://cke.gov.pl/images/_EGZAMIN_MATURALNY_OD_2015/Probny/2021/EPOP-P2-100-2103.pdf [dostęp: 30.04.2021].

Grabias S. (1994), Język w zachowaniach społecznych, Lublin.

Informator o egzaminie maturalnym z języka polskiego od roku szkolnego 2014/2015, https://www.cke.edu.pl/images/_EGZAMIN_MATURALNY_ OD_2015/Informatory/2015/Jezyk-polski.pdf [dostęp: 23.07.2017].

Ingarden R. (1967), Z teorii dzieła literackiego, w: Problemy teorii literatury, wybór H. Markiewicz, Wrocław.

Kaniewski J. (2007), Koncepcja egzaminu maturalnego a kształcenie polonistyczne. Konstrukcja tematów i kryteria oceniania prac pisemnych na tzw. Nowej Maturze, Poznań.

Kłakówna Z.A. (2016), Język polski. Wykłady z metodyki, Kraków.

Kurczab H. (2012), Z problemów wartości i wartościowania (wybrane zagadnienia), „Zeszyty Naukowe Uniwersytetu Rzeszowskiego. Seria Filologiczna. Dydaktyka 7" nr 72.

Mikołajczuk A. (2013), Modele gatunkowe tekstu pisanego przez uczniów na egzaminie maturalnym ( $w$ kontekście planowanej modernizacji matury z języka polskiego), „Poradnik Językowy” z. 1.

Nocoń J. (2016), Teksty argumentacyjne w edukacji językowo-komunikacyjnej, w: Szkice o dojrzałości, kulturze i szkole. Prace dedykowane Profesor Halinie Wiśniewskiej, red. M. Karwatowska, L. Tymiakin, Lublin.

Udzik B. (2019), , Rozważ i uzasadnij”. Struktury argumentacyjne w rozprawkach maturalnych (na poziomie podstawowym), Poznań.

Uryga Z. (1996), Godziny polskiego. Z zagadnień kształcenia literackiego, Warszawa.

[WSJP PAN] Wielki słownik języka polskiego (online), red. P. Żmigrodzki, https://www.wsjp.pl [dostęp: 28.04.2021]. 
[WSJP PWN] Wielki słownik języka polskiego (2018), red. Dubisz S., Warszawa.

Warchala J. (2003), Kategoria potoczności w języku, Katowice.

Warchala J. (2013), Uwagi o współczesnej piśmienności, „Konteksty Kultury" t. 10, nr 1-2.

Zinken J. (2004), Punkt widzenia jako kategoria w porównawczym badaniu dyskursów publicznych, w: Punkt widzenia w języku i w kulturze, red. J. Bartmiński, Lublin.

\section{Streszczenie}

Licealiści piszą o konsekwencjach podejmowanych decyzji. Analiza wybranych przykładów językowej konceptualizacji wyboru w pracach $\mathrm{z}$ matury próbnej

Tematem artykułu jest analiza materiału badawczego pochodzącego z uczniowskich rozprawek. Autorka rozważa sposób ujawniania się instrumentalnego i formacyjnego charakteru edukacji polonistycznej w wypowiedziach pisemnych uczniów. Analizuje leksykę wykorzystaną we wstępach wypracowań, zwłaszcza słowa kluczowe zadania. Podejmuje próbę odtworzenia językowej konceptualizacji problemu, który rozważali uczniowie na maturze próbnej z języka polskiego na poziomie podstawowym w 2021 r.: wpływ dokonywanych przez człowieka wyborów na jego życie.

Słowa kluczowe: język, konceptualizacja, rozprawka, wybór, pisanie

\section{Summary}

High school students write about the consequences of taken decisions. The analysis of selected examples of the linguistic conceptualization of the choice in the works on the mock exam.

The subject of the article is the analysis of the research material from the students' essays. The author considers how the instrumetal and formative character of Polish language education is revealed in students' essays. She analyzes the lexis used in the introductions of the essays, focusing on the key words. The author attempts to recreate the linguistic conceptualization of the problem which was considered by students on the Polish matura in 2021: the impact of choices made by a person on his/her life.

Keywords: language, conceptualization, essay, choice, writing 